\title{
Measurement of the optical density of packable composites - comparison between direct and indirect digital systems
}

\section{Mensuração da densidade óptica de compósitos compactáveis - comparação entre sistemas digitais direto e indireto}

\author{
Luiz Felipe Rodrigues Graziottin* \\ Nilza Pereira da Costa** \\ Ivori Dutra da Silveira* \\ Elaine Bauer Veeck**
}

\begin{abstract}
The aim of this study was to measure the optical density of four packable composite resins with widths of 1, 2, 3 and $4 \mathrm{~mm}$, by means of Digora ${ }^{\circledR}$ (direct) and DentScan DentView ${ }^{\circledR}$ (indirect) digital imaging systems, in order to compare both methods. Twenty acrylic plates, with the proposed thicknesses, were used, each one containing a sample of each resin. Each acrylic plate was radiographed three times, under a standardized technique. For the Digora ${ }^{\circledR}$ system, an optical plate was used under each resin sample, and, for the DentScan DentView ${ }^{\circledR}$ system, occlusal films were employed, totalizing 60 exposures for each system. Optical plates and films were scanned and three consecutive optical readouts were carried out, totalizing 1,440 readouts. The results were submitted to statistical analysis and revealed that the average optical density of the four resins always increased as thickness increased. Regarding the comparisons between the composite resins, in both analysis the resin with the greater optical density was Surefilim followed by Prodigy ${ }^{\mathrm{TM}}$ Condensable, Alert ${ }^{\mathrm{TM}}$ and Solitaire ${ }^{\circledR}$. The correlations between the results of Digora ${ }^{\circledR}$ and DentScan DentView $^{\circledR}$ were significant for the different thicknesses and materials. The observed tendency is that as the values obtained with the Digora ${ }^{\circledR}$ system increase, so do the values obtained with DentScan DentView ${ }^{\circledR}$. While thickness increased, the values of optical density in both Digora ${ }^{\circledR}$ and DentScan DentView ${ }^{\circledR}$ tended to approach each other. The Digo$\mathrm{ra}^{\circledR}$ system presented smaller amplitude between the results obtained in adjacent thicknesses.

DESCRIPTORS: Composite resins; Image processing, computer-assisted; Radiographic image enhancement.
\end{abstract}

\begin{abstract}
RESUMO: O objetivo deste estudo foi mensurar a densidade óptica de quatro resinas compostas compactáveis nas espessuras de 1, 2, 3 e 4 mm utilizando os sistemas de digitalização de imagens Digora ${ }^{\circledR}$ (direto) e DentScan DentView ${ }^{\circledR}$ (indireto) e compará-los entre si. Foram utilizadas 20 placas de acrílico nas espessuras propostas, cada uma contendo uma amostra de cada resina. Cada placa acrílica foi radiografada três vezes, sob técnica padronizada, usando, para o sistema Digora ${ }^{\circledR}$ uma placa óptica sob cada amostra de resina, e para o sistema DentScan DentView ${ }^{\circledR}$, filmes oclusais, totalizando 60 exposições para cada sistema. Após, as placas ópticas e os filmes foram escaneados, e fez-se três leituras ópticas consecutivas de cada imagem, totalizando 1.440 leituras. Os resultados submetidos à análise estatística, permitiram concluir que, foi sempre crescente a média de densidade óptica das quatro resinas com o aumento da espessura. Quanto à comparação entre as resinas compostas, nas duas análises a de maior densidade óptica foi a Surefil ${ }^{\mathrm{TM}}$, seguida em ordem decrescente, pelas resinas Prodigy ${ }^{\mathrm{TM}}$ Condensable, Alert $^{\mathrm{TM}}$ e Solitaire ${ }^{\circledR}$. As correlações entre os resultados do Digora ${ }^{\circledR}$ e DentScan DentView ${ }^{\circledR}$ foram significativas para as diferentes espessuras e materiais. A tendência observada é que à medida que os valores do Digora ${ }^{\circledR}$ aumentam, os valores do DentScan DentView $^{\circledR}$ também aumentam. Com o aumento das espessuras, os valores das médias de densidade óptica das

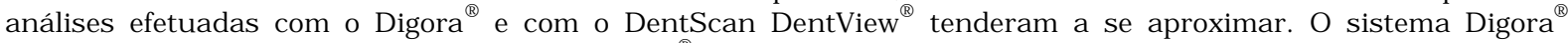
apresentou, comparado com o DentScan DentView ${ }^{\circledR}$, uma menor amplitude entre os valores das espessuras próximas. DESCRITORES: Resinas compostas; Processamento de imagens assistido por computador; Intensificação de imagem radiográfica.
\end{abstract}

\section{INTRODUCTION}

Recently, the industry has introduced packable composite resins of high viscosity to the market. It aimed at joining the characteristics of amalgam with the aesthetic and adhesive features of com- posite resins. Packable resins are manipulated in the same way as the well-known silver amalgam. Christensen $^{3}$ (1998) states that the differences formerly faced by professionals in confecting restorations with standard composite resins - such as defective proximal contour, blank spaces or voids in

${ }^{*}$ Master Degree in Restorative Dentistry; ${ }^{* *}$ Full Professor, Discipline of Radiology - School of Dentistry, Pontifical Catholic University of Rio Grande do Sul. 
Grazziottin LFR, Costa NP da, Silveira ID da, Veeck EB. Measurement of the optical density of packable composites - comparison between direct and indirect digital systems. Pesqui Odontol Bras 2002;16(4):299-307.

the material and lack of contact point - can be bypassed with the utilization of packable composite resins and improved matrices. Nash et al. ${ }^{10}$ (1998) sustain that dentists have now available an aesthetic restorative material whose technique they are familiar with. According to Iório ${ }^{8}$ (1999), materials of this nature will replace hybrid and microhybrid composite resins in posterior teeth restorations, and the utilization of current multi-purpose resins will be restricted to anterior teeth.

Muñoz Chávez et al. ${ }^{9}$ (1999) and Porto Neto, Machado $^{11}$ (1999) consider that, in order to obtain a complete success in the restorative treatment with composite resins, a periodic follow-up is required for clinical and, if necessary, radiographic evaluations of patients.

However, to assess the situation of restorations in periodic radiographic controls, besides good-quality radiographs, it is necessary that the restorative material presents good radiopacity. Radiopacity must be adequate so that one can: distinguish the restorative material from adjacent dental structures, as well as from secondary caries or decalcified dentin; evaluate marginal adaptation in the cervical margin; evaluate the proximal contour of the restoration and identify internal voids within the material, as stated by Figueredo et al. ${ }^{5}$ (1999) and Iório $^{8}$ (1999).

Farman et $a l^{4}{ }^{4}$ (1996) mention that the search for aesthetically satisfactory restorations without mercury justifies the importance of the image quality of new restorative materials.

In 1987, Watts ${ }^{14}$ recommended that, when data on the radiopacity of different materials are compared, values should be expressed "in equivalent aluminum thickness" (purity of 99.5\%). However, Figueiredo et $a l^{5}$ (1999) consider that the digitized image appears as a new resource for the evaluation of optical density - its unit, assessed by means of the computer, is called pixel.

The structural composition of packable composite resins arises scientific curiosity as to distinctions between the various commercial brands, especially regarding radiographic density and its expression. The result has great clinical importance, since it is a matter of concern not only for radiologists but also for clinicians, who must distinguish composite resins from other materials, dental structures, caries lesions and other alterations.

Comparing direct and indirect digital systems, we aimed at understanding a bit more about this new technology, and also to know more about the possibility of integrating both systems in the analysis of optical density.

Considering the exposed reasons, the survey is justified. It aims to evaluate and compare the optical densities of different packable composite resins, in specimens of 1, 2, 3 and $4 \mathrm{~mm}$, by measn of digital radiographic images, also comparing the results obtained by means of two different systems of digital radiology.

\section{MATERIALS AND METHOD}

During this survey, four brands of light-curing packable composite resins were used: Alert ${ }^{\mathrm{TM}}$ (Jeneric/Pentron) shade clear, Prodigy ${ }^{\mathrm{TM}}$ Condensable (Sybron/Kerr) shade A1, Solitaire ${ }^{\circledR}$ (Heraeus Kulzer) shade I and Surefil ${ }^{\mathrm{TM}}$ (Dentsply/Caulk) shade A, all within their valid terms.

\section{Preparation of samples}

Twenty translucent acrylic plates of 1, 2, 3 and $4 \mathrm{~mm}$ were confected with $5.7 \mathrm{~cm} \mathrm{x} 7.1 \mathrm{~cm}$. They were calibrated using a 1-mm-accuracy thickness gauge (Mitutoyo), and there were five plates of each thickness.

Each plate was divided in four quadrants. A hole with the diameter of $4 \mathrm{~mm}$ was confected at the centre of each quadrant. The depth of each hole corresponded to the total thickness of each plate. The hole served as a site for the insertion and compaction of the examined resins.

At the border of each hole of the same plate, a round clockwise niche was confected, each one corresponding to the position of clock figures 3,6 , 9 and 12. These niches served as references for the insertion of the respective resin and were used to drain the excess of material.

To identify the thickness of plates, each one received on its left upper edge the corresponding number of perforations with a number 2 spherical drill. The perforations were then filled with conventional composite resin, to improve their visualization. Likewise, with the intention of individualizing each plate, 1 to 5 vertical incisions were confected in the upper edge of each plate of equal thickness, which were also filled with conventional composite resin.

The twenty acrylic plates were then attached, with adhesive tape (3M), one at a time, to a smooth translucent glass plate of $5 \mathrm{~mm}$, which was lined with a plastic flake for translucence (Maxprint ${ }^{\circledR}$ ), slashed in the same dimensions. 
Grazziottin LFR, Costa NP da, Silveira ID da, Veeck EB. Measurement of the optical density of packable composites - comparison between direct and indirect digital systems. Pesqui Odontol Bras 2002;16(4):299-307.

The restorative materials were inserted and compacted in their respective orifices, without hand contact, since the operator's hands were covered with rubber gloves (Polymed ${ }^{\circledR}$ ) for clinical procedures. Resins were inserted and compacted following the alphabetic order of the materials' commercial names, in a clockwise sequence, starting at the upper left quadrant. Thus, the Alert ${ }^{\mathrm{TM}}$ resin was always inserted in the orifice located in the upper left quadrant, Prodigy ${ }^{\mathrm{TM}}$ Condensable in the orifice of the upper right quadrant, Solitaire ${ }^{\circledast}$ in the orifice of the lower right quadrant and Surefil ${ }^{\mathrm{TM}}$ in the orifice of the lower left quadrant.

Insertion was carried out with a plastic amalgam container, in increments of $2 \mathrm{~mm}$. Compaction was carried out with a spatula for composite resins (number 6 - Thompson). Each increment was light-cured for 40 seconds (Gnatus Opt light 600), with the intensity of light checked through a radiometer (Cure Rite Efos), which revealed the value of $420 \mathrm{~mW} / \mathrm{cm}^{2}$.

After the compaction of the last or single increment, the material was pressed by means of a translucent smooth glass plate covered with a plastic film for translucency (Maxprint ${ }^{\circledR}$ ) cut in the same size, so as to limit the inserted resin thickness and to level its surface. Special care was taken to avoid total sealing of the niche area, so that the excess of resin could flow without resistance. Light-curing was than carried out for 10 seconds over the kit glass plate/plastic film. Once ceased this first light-curing step, the glass plate was removed and light-curing was completed for another 30 seconds.

After light-curing, plates were protected with food-packing PVC film, in order to prevent contamination.

\section{Obtainment of radiographs by means of the Digora ${ }^{\circledR}$ digital system}

Four small-sized optical plates, with the dimensions of $26 \times 35 \times 1.6 \mathrm{~mm}$, from the direct digitizing system Digora ${ }^{\circledR}$ were used (Soredex, Orion Corporation, Helsinki, Finland).

A preliminary test was carried out. It varied the exposure time in order to determine which digital image showed the best density and contrast, according to the agreement of two specialists in dental radiology. This evaluating modality is a rule of the Discipline of Radiology, School of Dentistry, PUC-RS.

The standardization of the digital images was obtained according to the following description:
- Utilization of an x-ray device (Dabi-Atlante ${ }^{\circledast}$ ) with electrical regime of $70 \mathrm{kVp}, 50 / 60 \mathrm{~Hz}$ and $8 \mathrm{~mA}$;

- Exposure time of $0.05 \mathrm{~s}$;

- maintenance of $40 \mathrm{~cm}$ of focal distance;

- $\mathrm{x}$-ray central beam perpendicular to the center of the acrylic plate.

Each set of plates (five plates) was radiographed in the same session. The optical plates, before each exposure, were properly packed in their individual plastic envelopes that accompany the system.

Each acrylic plate was radiographed as follows: on a Formica ${ }^{\mathrm{TM}}$ surface references were drew so as to allow standardized positioning of the acrylic plates/optical plates set. Each optical plate was placed under each acrylic plate quadrant so that each resin specimen was as centralized as possible. After a 0.05-second exposure, the optical plates were submitted to scanning and digitizing.

Three radiographs of each plate were obtained, totalizing 15 radiographs of each thickness in order to minimize the probability of error due to possible variation of the electric current during the obtainment of radiographs or during the scanning process.

\section{Obtainment of radiographs with the Dentscan Dentview ${ }^{\circledR}$ digital system}

Occlusal Kodak $^{\circledast}$ films (number 4, Ektaspeed Plus) were utilized. They had the same emulsion number (2100790 2000-10) and were within their validity term.

A preliminary test was carried out by varying the exposure time, in order to verify which radiograph would present the best visual contrast and density, according to the agreement of two specialists in dental radiology.

The standardization of radiographs was obtained by means of the following parameters:

- utilization of an x-ray device (Dabi-Atlante ${ }^{\circledR}$ ) with an electrical regime of $70 \mathrm{kVp}, 50 / 60 \mathrm{~Hz}$ and $8 \mathrm{~mA}$;

- exposure time of $0.4 \mathrm{~s}$;

- maintenance of focal distance in $40 \mathrm{~cm}$;

- automatic processing in an AT 2000 Air Techniques Inc. machine, standardized at $29^{\circ} \mathrm{C}$, with a processing time, of 4 minutes and $30 \mathrm{sec}-$ onds (dry to dry) and utilization of a Kodak ${ }^{\circledast}$ $\mathrm{X}$-OMAT fixer and developer;

- $\mathrm{x}$-ray central beam perpendicular to the center of the film.

All radiographic plates and films were previously identified according to the previously men- 
Grazziottin LFR, Costa NP da, Silveira ID da, Veeck EB. Measurement of the optical density of packable composites - comparison between direct and indirect digital systems. Pesqui Odontol Bras 2002;16(4):299-307.

tioned codes. Three radiographs of each plate were obtained, totalizing 15 radiographs of each thickness, in order to minimize the probability of error due to possible variation of the electric current during the obtainment of radiographs, film defects or failure during film processing.

\section{Image digitizing with the Digora ${ }^{\circledR}$ digital system}

Image digitizing was carried out in a room with poor lighting, by means of the Digora ${ }^{\circledR}$ direct image digitizing system (Soredex Orion Corporation, Helsinki, Finland).

Each optical plate was unpacked and introduced in the laser reading. The optical plate that held the Alert ${ }^{\mathrm{TM}}$ resin image was always the first to be introduced in the scanner, always following the alphabetical order.

Each radiograph was identified, within the system, by means of three digits: the first corresponded to the acrylic plate thickness, the second stood for the plate number and the third indicated the number of the radiographic shot. For example, number 432 meant: $4 \mathrm{~mm}$ of thickness, plate number $3,2^{\text {nd }}$ radiographic shot.

For optical reading, an area of $20 \times 20$ pixels was selected, with $\mathrm{x}$ and $\mathrm{y}$ coordinates, located near the center of each resin specimen. For each resin, three readings were carried out on each radiograph. Since there were three radiographs from each plate, a total of 36 readings by plate were obtained. Once we worked with 20 plates, (5 for each thickness), a total of 720 optical readings were obtained.

Both image digitalization and optical readings were always carried out by the same professional.

The mean value of optical density for each composite resin was written down, and the data were analyzed by means of statistical tests - analysis of variance (ANOVA) and Tukey multiple comparisons tests at a significance level of $1 \%$ - generating results which are presented in graphs.

\section{Image digitizing with the DentScan DentView ${ }^{\circledR}$ digital system}

The APICA Eng. Ltda. DentScan DentView ${ }^{\otimes}$ System - Dental Technologies (1994) was utilized.

The digitized radiographic image was obtained by scanning each radiograph, one at a time, with the aid of a proper sheet supplied by the manufacturer. The hands of the operator were always protected by gloves. The digitized radiographic image was enlarged three times for better image resolution. A digital millimeter grid was applied over this image on the monitor, which allowed to establish density. The "avanzados" function and the density-measuring tools were applied, which allowed selecting the image areas where optical readout was carried out through the display of numbers, after a click with the mouse.

For each of the 60 radiographic images corresponding to a packable composite resin, three optical readouts were carried out. Thus, for each resin there were 45 readouts of each thickness, totalizing 180 optical readouts from the same resin for the four studied thicknesses. Considering that four packable composite resins were studied, 720 optical readouts were obtained.

Both image digitalization and optical readings were always carried out by the same professional.

The outcomes were expressed in graphs and analyzed by means of the statistical test ANOVA.

\section{RESULTS}

Based on the objectives and methodology employed in the present research, whose aim was to evaluate and compare the optical density of packable composite resins in different thicknesses by means of the Digora ${ }^{\circledR}$ and DentScan DentView ${ }^{\circledR}$ digitizing systems, it was possible to gather data, which were analyzed by means of the following statistical tests: analysis of variance (ANOVA), multiple comparisons Tukey test with the significance level of $1 \%$, as well as correlation analysis (Pearson correlation coefficient).

\section{Comparison between thicknesses by means of the DentS can DentView ${ }^{\circledR}$ digital system}

Through the analysis of variance the results revealed that for the four packable resins - Alert ${ }^{\mathrm{TM}}$, Prodigy $^{\mathrm{TM}}$ Condensable, Solitaire ${ }^{\circledR}$ and Surefil ${ }^{\mathrm{TM}}-$, the thickness of $1 \mathrm{~mm}$ showed the smallest values of optical density, followed by 2,3 and $4 \mathrm{~mm}$. The two latter thicknesses did not differ from each other $(\mathrm{p}=0.01)$ (Graph 1).

\section{Comparison between thicknesses by means of the Digora ${ }^{\circledR}$ digital system}

Through the results of the analysis of variance, we could observe that, for the four packable resins - Alert $^{\mathrm{TM}}$, Prodigy ${ }^{\mathrm{TM}}$ Condensable, Solitaire ${ }^{\circledast}$ and Surefil $^{\mathrm{TM}}-$, the thickness of $1 \mathrm{~mm}$ showed the smallest values of optical density, followed by 2 and $3 \mathrm{~mm}$, which did not differ from each other, and by the thickness of $4 \mathrm{~mm}$, which differed from 
Grazziottin LFR, Costa NP da, Silveira ID da, Veeck EB. Measurement of the optical density of packable composites - comparison between direct and indirect digital systems. Pesqui Odontol Bras 2002;16(4):299-307.

all the others, presenting the highest value of optical density ( $\mathrm{p}=0.01$ ) (Graph 2).

\section{Comparison between resins by means of the DentScan DentView ${ }^{\circledR}$ digital system}

By means of the analysis of variance, it was observed that, with the thickness of $1 \mathrm{~mm}$, the Solitaire ${ }^{\circledast}$ resin shows the smallest values of optical density, followed, in increasing order, by Alert ${ }^{\mathrm{TM}}$ and Prodigy $^{\mathrm{TM}}$ Condensable, and, finally, by Surefil ${ }^{\mathrm{TM}}$, which presents a higher value, although it was not statistically different from Prodigy ${ }^{\mathrm{TM}}$ Condensable (p = 0.01) (Graph 3).

It was observed that, for the thicknesses of 2,3 and $4 \mathrm{~mm}$, Solitaire ${ }^{\circledR}$ presented the lowest values,

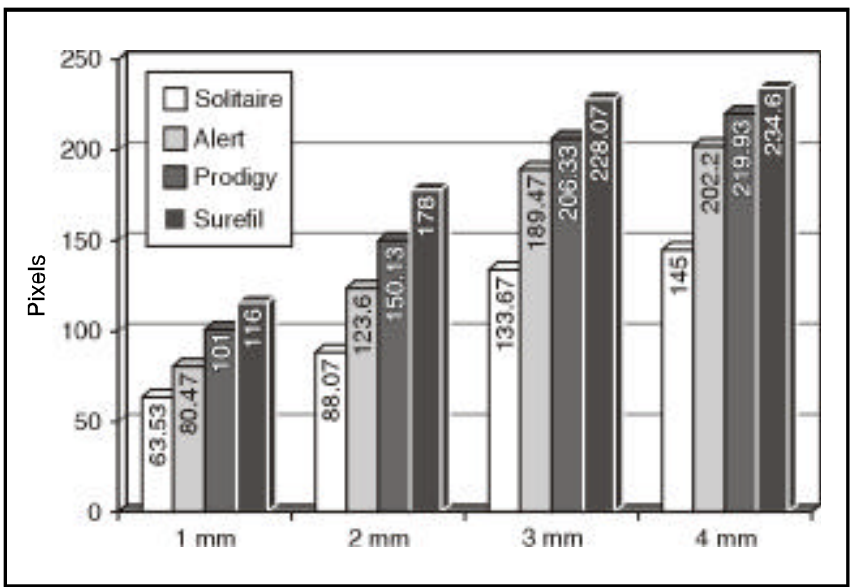

GRAPH 1- Mean values of optical density of each of the four packable composite resins, using the DentScan DentView ${ }^{\circledR}$ digital system. Porto Alegre, 2002.

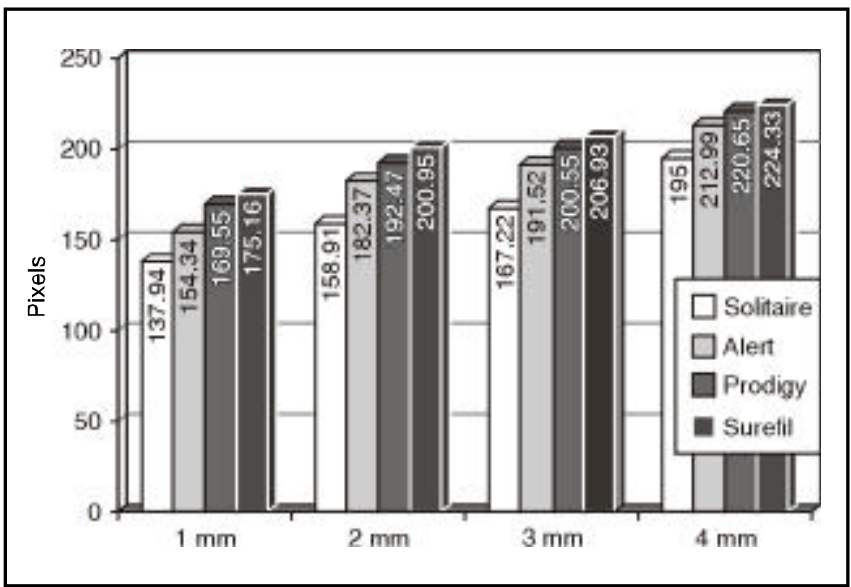

GRAPH 2 - Mean values of optical density of each of the four packable composite resins, using the Digora ${ }^{\circledR}$ digital system. Porto Alegre, 2002. followed, in increasing order, by Alert ${ }^{\mathrm{TM}}$ and Prodigy ${ }^{\mathrm{T}} \mathrm{M}$ Condensable, and, finally, by Surefil ${ }^{\mathrm{TM}}$. There were statistical differences between all of them $(p=0.01)$ (Graph 3).

\section{Comparison between resins by means of the Digora ${ }^{\circledR}$ digital system}

By means of the analysis of variance, it was observed that, for the thicknesses of 1 and $3 \mathrm{~mm}$, Solitaire ${ }^{\circledR}$ presented the lowest value of optical density, followed by Alert ${ }^{\mathrm{TM}}$ and Prodigy ${ }^{\mathrm{TM}}$ Condensable, which did not differ from each other, and finally, by Surefil ${ }^{\mathrm{TM}}$, which presented the highest value, although it was not statistically different from Prodigy ${ }^{\mathrm{TM}}$ Condensable $(\mathrm{p}=0.01)$ (Graph 4).

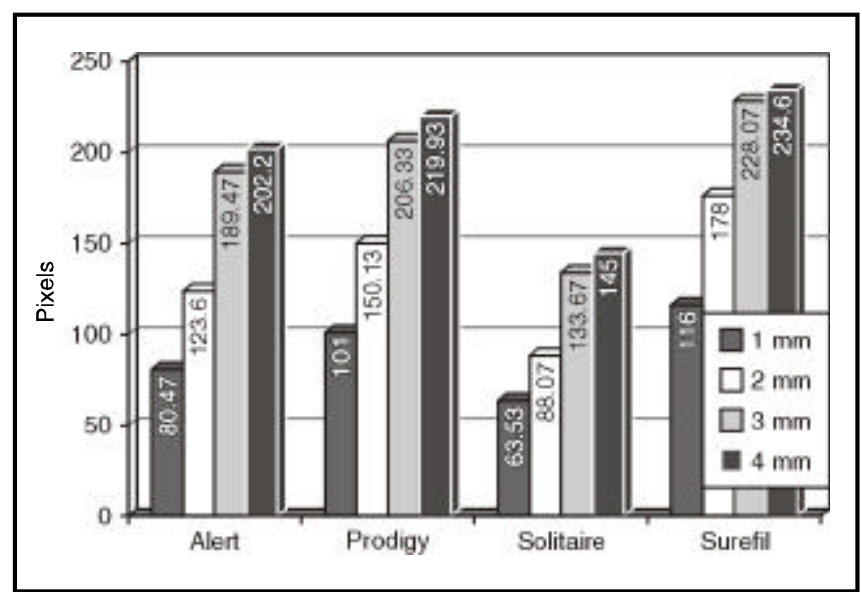

GRAPH 3 - Mean values of optical density of each of the four packable composite resins, in the different analyzed thicknesses, using the DentScan DentView ${ }^{\circledR}$ digital system. Porto Alegre, 2002.

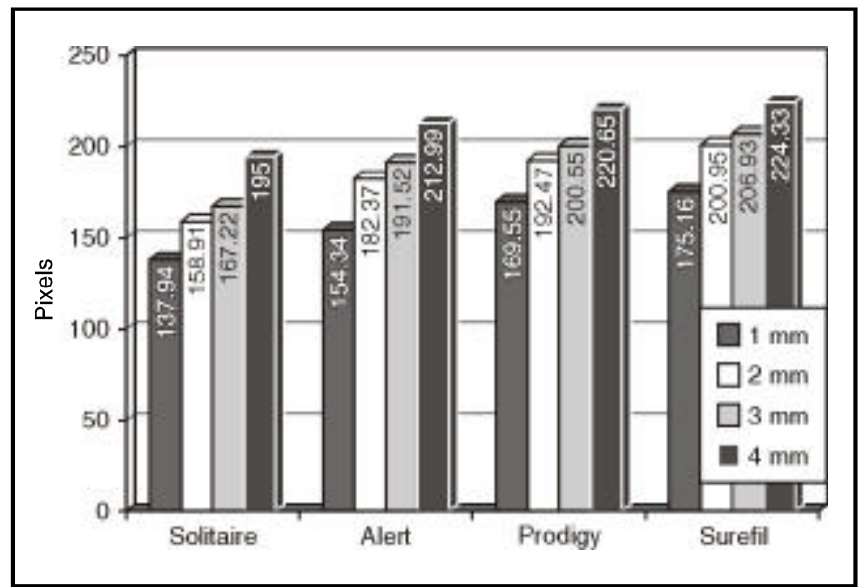

GRAPH 4 - Mean values of optical density of each of the four packable composite resins, in the different analyzed thicknesses, using the Digora ${ }^{\circledR}$ digital system. Porto Alegre, 2002. 
Grazziottin LFR, Costa NP da, Silveira ID da, Veeck EB. Measurement of the optical density of packable composites - comparison between direct and indirect digital systems. Pesqui Odontol Bras 2002;16(4):299-307.
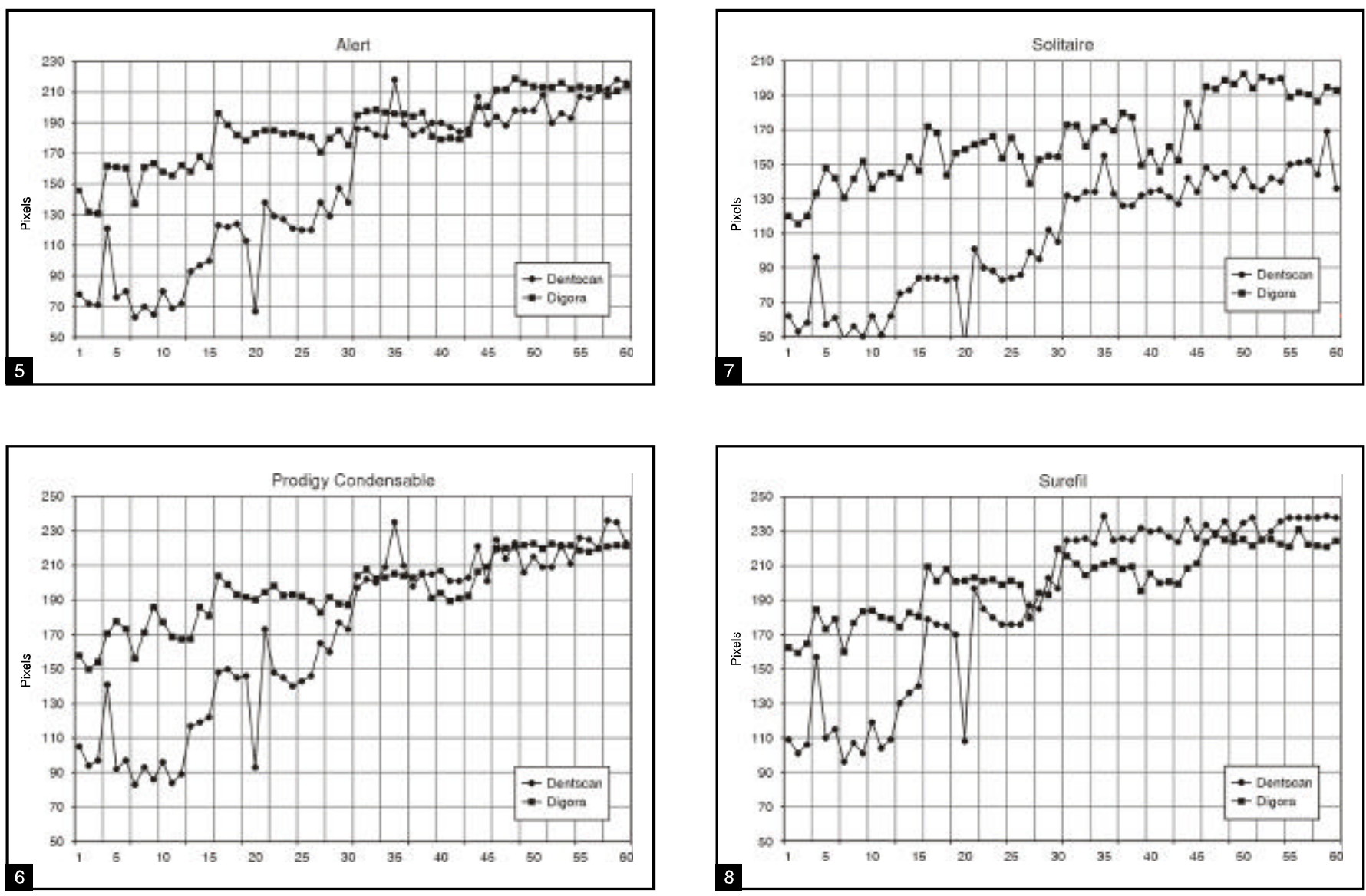

GRAPHS 5, 6, 7 and 8 - Comparison between the values of optical density obtained by means of the DentScan DentView $^{\circledR}$ and Digora ${ }^{\circledR}$ digital systems, for each of the four packable composite resins. Porto Alegre, 2002.

TABLE 1 - Results of the analysis of correlation, considering thicknesses. Porto Alegre, 2002.

\begin{tabular}{|c|c|c|}
\hline Thickness & $\begin{array}{l}\text { Pearson correlation coefficient between } \\
\text { Digora }^{\circledR} \text { e DentScan DentView }\end{array}$ & $\mathrm{p}$ \\
\hline $1 \mathrm{~mm}$ & 0.748 & 0.001 \\
\hline $2 \mathrm{~mm}$ & 0.765 & 0.001 \\
\hline $3 \mathrm{~mm}$ & 0.873 & 0.001 \\
\hline $4 \mathrm{~mm}$ & 0.927 & 0.001 \\
\hline
\end{tabular}

It was observed that there are significant differences between the averages of optical density of the four studied resins for the thickness of $2 \mathrm{~mm}$ $(p=0.01)$. Solitaire ${ }^{\circledR}$ presented the lowest value, followed by Alert ${ }^{\mathrm{TM}}$, Prodigy ${ }^{\mathrm{TM}}$ Condensable, and Surefil $^{\mathrm{TM}}(\mathrm{p}=0.01)(\mathrm{Graph} 4)$.
TABLE 2 - Results of the analysis of correlation, considering materials. Porto Alegre, 2002.

\begin{tabular}{|c|c|c|}
\hline Material & $\begin{array}{c}\text { Pearson correlation coefficient between } \\
\text { Digora }^{\circledast} \text { e DentScan DentView }\end{array}$ & $\mathrm{p}$ \\
\hline Alert ${ }^{\mathrm{TM}}$ & 0.868 & 0.001 \\
\hline $\begin{array}{l}\text { Prodigy }^{\mathrm{TM}} \\
\text { Condensable }\end{array}$ & 0.861 & 0.001 \\
\hline Solitaire $^{\circledR}$ & 0.792 & 0.001 \\
\hline Surefil ${ }^{\mathrm{TM}}$ & 0.869 & 0.001 \\
\hline
\end{tabular}

It was also observed that, for the thickness of $4 \mathrm{~mm}$, Solitaire ${ }^{\circledast}$ presented the lowest value of optical density, followed by Alert ${ }^{\mathrm{TM}}$, and Prodigy ${ }^{\mathrm{TM}}$ Condensable, which differed from each other, and finally, by Surefil ${ }^{\mathrm{TM}}$ resin, which presented the highest value, although with no statistical differ- 
Grazziottin LFR, Costa NP da, Silveira ID da, Veeck EB. Measurement of the optical density of packable composites - comparison between direct and indirect digital systems. Pesqui Odontol Bras 2002;16(4):299-307.

ence in relation to Prodigy ${ }^{\mathrm{TM}}$ Condensable $(\mathrm{p}=0.01)$ (Graph 4).

\section{Comparison between the DentScan DentView ${ }^{\circledR}$ and the Digora ${ }^{\circledR}$ digital systems}

In order to assess the occurrence of significant correlation between the measurements obtained by means of DentScan DentView ${ }^{\circledR}$ and Digora ${ }^{\circledR}$, analysis of correlation was applied to the variables thickness and material (Tables 1 and 2).

The correlations between the results obtained with Digora ${ }^{\circledR}$ and DentScan DentView ${ }^{\circledR}$ were significant, for different thicknesses and materials. The observed tendency was that as the Digora ${ }^{\circledast}$ values increased, so did the DentScan DentView ${ }^{\circledast}$ values (Graphs 5, 6, 7 and 8).

\section{DISCUSSION}

The utilization of digital image in this work was due to the fact that this technology diminishes the variables that correspond to human limitations, and also to the great repercussion of this technology in different dental specialties. It offers a great number of tools and benefits, such as the dramatic decrease in the radiation dose, the decreased working time, the possibility of working on-line (image transmission), among others.

Bustamante et al. ${ }^{2}$ (1998) stated that, in a near future, digital systems will be part of the dentist's instruments, for patients' safety and protection. Thus, it is said that within a short period of time, digital imaging will be the chosen methodology for the evaluation of the optical density of materials.

The method for the validation of readings employed in this study was also utilized by Farman et al. ${ }^{4}$ (1996); Gürdal, Akdeniz ${ }^{6}$ (1998); Figueiredo et $a l .{ }^{5}$ (1999) and Ramalho et al. ${ }^{12}$ (1999), who also used the digital image resource for the evaluation of the optical density of other dental materials.

In the comparison between the different analyzed thicknesses, the results obtained by means of Digora $^{\circledast}$ were similar to the those obtained with DentScan DentView ${ }^{\circledR}$, for, in both, there was increasing optical density as thickness increased. There was no statistically significant difference between the thicknesses of 2 and $3 \mathrm{~mm}$ with Digora ${ }^{\circledast}$, while the same was observed between the thicknesses of 3 and $4 \mathrm{~mm}$, when DentScan DentView ${ }^{\circledR}$ was employed. As to the comparison between the evaluated composite resins, in both analyses, the greatest optical density was observed for Surefil ${ }^{\mathrm{TM}}$, followed by
Prodigy $^{\mathrm{TM}}$ Condensable, Alert ${ }^{\mathrm{TM}}$ and Solitaire ${ }^{\circledast}$. The latter, in both analysis, always presented the smallest optical density. However, with DentScan DentView $^{\circledR}$ there was no statistically significant difference between Surefil ${ }^{\circledR}$ and Prodigy ${ }^{\mathrm{TM}}$ Condensable, for the thickness of $1 \mathrm{~mm}$. With Digora ${ }^{\circledR}$, the mean values of optical density were similar for Alert ${ }^{\mathrm{TM}}$ and Prodigy ${ }^{\mathrm{TM}}$ Condensable, and also for Prodigy ${ }^{\mathrm{TM}}$ Condensable and Surefil ${ }^{\mathrm{TM}}$, for thicknesses of 1 and $3 \mathrm{~mm}$. No statistically significant difference was observed between the mean values of optical density of Prodigy ${ }^{\mathrm{TM}}$ Condensable and Surefil ${ }^{\mathrm{TM}}$, for the thickness of $4 \mathrm{~mm}$, at the level of significance of $1 \%$. The deviation standards of the values of optical density analyzed by Digora $^{\circledast}$ were a lot inferior to the deviation standards of the values of optical density obtained by means of DentScan DentView ${ }^{\circledR}$. The high optical density of Prodigy ${ }^{\mathrm{TM}}$ Condensable and Surefil ${ }^{\mathrm{TM}}$ suggests that their inorganic filling components present chemical elements with high atomic number, or that such components are present in greater concentration, which provides them with higher radiopacity. Alert ${ }^{\mathrm{TM}}$ and Solitaire ${ }^{\circledast}$ present lower values of optical density since they do not contain chemical elements with high atomic numbers and present lower concentrations of inorganic filling components. These results are in accordance with the information provided by Leinfelder et al. (1999) as to packable composites - the authors present Surefil $^{\mathrm{TM}}$ as a high-radiopacity resin, and Solitaire ${ }^{\circledR}$, as a low-radiopacity resin. However, they do not classificate the Prodigy ${ }^{\mathrm{TM}}$ Condensable resin.

Within the same thickness, for each one of the resins, Digora ${ }^{\circledR}$ presented higher and more homogenous values, which means that there was lower amplitude. The same was reported by Bustamante et $a .^{2}{ }^{2}$ (1998), when they tested the validity of both systems in a study on osseointegrated implants, comparing the obtained results as to their distribution standard and evaluating the influence of titanium implants on the optical density of the perimplant area. Barros ${ }^{1}$ (2000) evaluated the optical density of bone by means of digitized images, in the retromolar region of ten corpses, using the digital systems DentScan DentView ${ }^{\otimes}$ and Digora ${ }^{\circledR}$ (both in an indirect way), and also reported the lower amplitude of the results obtained by means of the latter system.

The correlations between the results obtained with Digora $^{\circledR}$ and with DentScan DentView ${ }^{\circledR}$ were 
Grazziottin LFR, Costa NP da, Silveira ID da, Veeck EB. Measurement of the optical density of packable composites - comparison between direct and indirect digital systems. Pesqui Odontol Bras 2002;16(4):299-307.

significant for different thicknesses and materials. The observed tendency was that, as Digora ${ }^{\circledR}$ values increased, so did the values obtained with DentScan DentView ${ }^{\circledast}$. This tendency had already been reported by Henkin ${ }^{7}$ (1999), in the in vivo evaluation of the differences between the optical density of the dentin adjacent to decalcified and sound images, in upper and lower premolars, by means of DentScan DentView ${ }^{\circledR}$ and Digora ${ }^{\circledR}$ (both in an indirect way). The author attributes the numerical differences between the systems to the different types of equipment for image caption.

Ramalho et al. ${ }^{12}$ (1999) also compared the same gray level obtained through different digital systems. In that work, indirect digitized radiographs were obatined by means of the DentScan DentView ${ }^{\circledR}$ system and captured images were obtained by means of the optical plates of the Digora ${ }^{\circledR}$ system optical plates. They were analyzed as to the mean gray level obtained for root canals, before and after filling. The results revealed statistically significant differences between the values, proving that each system has its own scale of brightness and contrast, and that the data obtained in a specific system should not be extended to others. The authors believe that the main responsible for the differences between the gray level values was the method of digitizing utilized in each system. Indirectly digitized radiographs tend to present higher variation of the gray level, since readout depends on the specific characteristics of the scanner. In direct digitizing systems of the CR type, such as Digora ${ }^{\circledR}$, the gray levels of each pixel correspond to the optical plate particles of phosphorous due to $\mathrm{x}$-radiation, and perhaps, the result of this conversion is more exact. Anyway, it is understood that direct and indirect digitizing systems must have their own gray scale references for possible different analyses.

One can notice that, with the increase in thicknesses, the mean values of optical density obtained by means of Digora $^{\circledR}$ and DentScan DentView $^{\circledR}$ tended to approximate.

Versteeg et al. ${ }^{13}$ (1997) consider that direct digital imaging is more efficient than indirect digital imaging. Gürdal, Akdeniz ${ }^{6}$ (1998) stated that direct digital imaging decreases the loss of information that can occur in indirect digitizing. More works must be developed in order to confirm this statement.

\section{CONCLUSIONS}

Once the results on the optical density of packable composite resins were analyzed by means of the Digora ${ }^{\circledast}$ and DentScan DentView ${ }^{\circledast}$ digital image systems, it was possible, with the methodology proposed in this study, to conclude that:

- the mean optical density of the four packable composite resins always increased as thickness increased, in both sistems;

- as to the comparison between the composite resins, in both analyses, the resin with the greatest optical density was Surefil ${ }^{\mathrm{TM}}$, followed by Prodigy ${ }^{\mathrm{TM}}$ Condensable, Alert ${ }^{\mathrm{TM}}$ and Solitaire ${ }^{\circledR}$ - the latter was always the one with the lowest optical density, in both analyses;

- in spite of the reliability of the digital methods utilized here to measure the optical density of packable composite resins, they should not be used in a same case, in different stages. On the contrary, comparisons should always be carried with the same method, since the numerical values that refer to optical density are different in these systems. Even so, it was observed that the correlations between the results of Digora ${ }^{\circledR}$ and DentScan DentView ${ }^{\circledR}$ were significant for different thicknesses and materials. The observed tendency is that, as the values obtained with Digora ${ }^{\circledR}$ increase, so do the values obtained with DentScan DentView ${ }^{\circledR}$;

- with an increase in thickness, the values of optical density obtained by means of Digora ${ }^{\circledR}$ and DentScan DentView ${ }^{\circledast}$ tended to approximate;

- when compared to DentScan DentView ${ }^{\circledR}$, the Digora $^{\circledR}$ system presented a lower amplitude between the values obtained for adjacent thicknesses.

\section{REFERENCES}

1. Barros FJBC. Avaliação óptica da densidade óssea na região retromolar em mandíbulas de cadáveres com tecidos moles intactos, através do uso de imagens digitalizadas [Tese] Porto Alegre: Faculdade de Odontologia Pontifícia Universidade Católica do Rio Grande do Sul; 2000.

2. Bustamante NP, Veeck EB, Costa NP. Análise óptica da densidade de implantes de titânio e sua influência na região periimplantar em diferentes sistemas de radiografias digitais. Rev Bras Cir Implant 1998;5(4):67-78.

3. Christensen GJ. Amalgam versus composite resin: 1998. J Am Dent Assoc 1998;129(12):1757-9. 
4. Farman TT, Farman AG, Scarfe WC, Goldsmith LJ. Optical densities of dental resin composites: a comparison of CCD, storage Phosphor, and Ektaspeed Plus radiographic film. Gen Dent 1996;44:532-7.

5. Figueiredo JAP, Vidor M, Bento LW, Boucinha ACD, Leipelt K, Silveira BT, Barbisan AO, Caminha JAN. Avaliação da radiopacidade de quatro marcas de resinas compostas fotopolimerizáveis através de imagem digitalizada. Stomatos 1999;8:15-22.

6. Gürdal P, Akdeniz BG. Comparison of two methods for radiometric evaluation of resin-based restorative materials. Dento-Maxillo-Facial Radiology 1998;27(4):236-9.

7. Henkin IMT. Avaliação da densidade óptica da dentina, em faces proximais de pré-molares hígidos e com cárie de esmalte, através da utilização de sistemas indiretos de análise digital. [Dissertação de Mestrado] Porto Alegre: Faculdade de Odontologia, Pontifícia Universidade Católica do Rio Grande do Sul; 1999.
8. Iório PAC. Resinas Compostas. In: Iório PAC. Dentística Clínica: Adesiva e Estética. São Paulo: Santos; 1999. p. 88-124.

9. Muñoz Chávez OF, Reis JIL, Santos LM, Andrade MF. Resinas compostas compactáveis - relato de caso clínico. J Bras Clín Estét Odontol 1999;3(16):11-7.

10. Nash RW, Radz GM, Leinfelder KF. A report on a new condensable composite resin. Compendium of continuing education in dentistry 1998;16(3):230-7.

11. Porto Neto ST, Machado CT. Resinas condensáveis. J Bras Odontol Clín 1999;3(13):35-9.

12. Ramalho LMP, Sarmento VA, Spohr AM, Löf AS, Costa NP. Mensuração da densidade óptica de áreas de imagens radiográficas - comparação entre um sistema digital direto e um indireto. Revista Odontológica da Universidade de Santo Amaro 1999;4(2):48-50.

13. Versteeg $\mathrm{CH}$, Sanderink GCH, Van Der Stelt PF. Efficacy of digital intra-oral radiography in clinical dentistry. J Dent 1997;25(3-4):215-24.

14. Watts DC. Characterization of aluminum radiopacity standards for restorative materials. J Dent 1987;15(4):175-7.

Recebido para publicação em 07/02/02

Enviado para reformulação em 20/06/02 Aceito para publicação em 22/07/02 